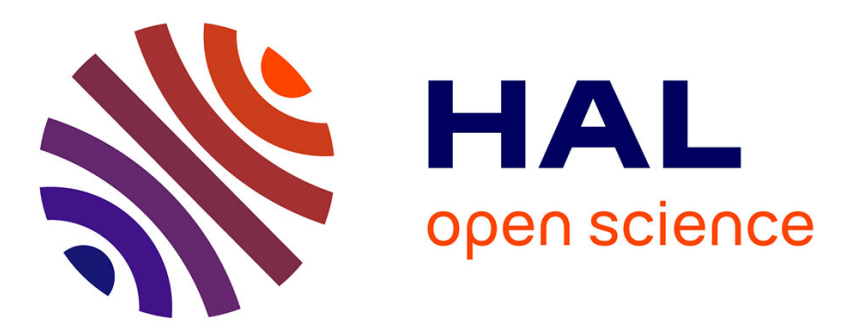

\title{
Decomposition rate and invertebrate colonization of seagrass detritus along a hydrodynamic gradient in a Mediterranean coastal basin: The Stagnone di Marsala (Italy) case study
}

\author{
Valentina Costa, Antonio Mazzola, Francesca Rossi, Salvatrice Vizzini
}

\section{To cite this version:}

Valentina Costa, Antonio Mazzola, Francesca Rossi, Salvatrice Vizzini. Decomposition rate and invertebrate colonization of seagrass detritus along a hydrodynamic gradient in a Mediterranean coastal basin: The Stagnone di Marsala (Italy) case study. Marine Ecology, 2019, 40 (6), pp.e12570. 10.1111/maec.12570 . hal-02399814

\section{HAL Id: hal-02399814 https://hal.science/hal-02399814}

Submitted on 14 Dec 2020

HAL is a multi-disciplinary open access archive for the deposit and dissemination of scientific research documents, whether they are published or not. The documents may come from teaching and research institutions in France or abroad, or from public or private research centers.
L'archive ouverte pluridisciplinaire HAL, est destinée au dépôt et à la diffusion de documents scientifiques de niveau recherche, publiés ou non, émanant des établissements d'enseignement et de recherche français ou étrangers, des laboratoires publics ou privés. 
$8{ }^{1}$ Department of Earth and Marine Sciences, University of Palermo, CoNISMa, Via Archirafi 18, 90123

9 Palermo, Italy

$10{ }^{2}$ Current address: Department of Biology \& CESAM, University of Aveiro, Campus Universitário de Santiago, $113810-193$, Aveiro, Portugal coastal basin: the Stagnone di Marsala (Italy) case study

\section{Decomposition of seagrass leaf litter}

\author{
Valentina Costa ${ }^{1,2^{*}}$, Antonio Mazzola ${ }^{1,3}$, Francesca Rossi ${ }^{4}$, Salvatrice Vizzini ${ }^{1,3}$
}

${ }^{3}$ CoNISMa, Interuniversity National Consortium for Marine Sciences, Piazzale Flaminio 9, 00196 Roma, Italy

${ }^{4}$ Université Côte d'Azur, CNRS, FRE 3729 ECOMERS, Nice, France

${ }^{*}$ Corresponding author.

E-mail address: vale.costa@gmail.com

\section{Acknowledgements}

This study was supported by the Flagship Project RITMARE—Italian Research for the Sea-funded by the Italian Ministry of Education, University and Research. We are grateful to A. Savona for field assistance and E. A. Aleo for help with laboratory analyses.

\section{Abstract}

Seagrass leaf litter decomposition is a key component of marine carbon flow driven by both biotic and abiotic factors, including water movement. In this study, we analyse Posidonia oceanica litter decomposition and invertebrate colonization in three sites with different hydrodynamics in a coastal basin. Litterbags were put on the seabed along a gradient of distance from the open-sea, implying a different level of water exchange. Leaf litter mass loss and carbon and nitrogen concentration were analysed and density and biomass of benthic invertebrates colonising litterbags were recorded after 3, 7, 14, 47, 101, 152 and 221 days. Results showed that in the most sheltered site, the leaf litter decomposition rate, the invertebrate density and biomass and the detrital carbon release were the lowest. The reduction of the decomposition rates of seagrass leaves in 
32 the site characterised by low hydrodynamic forces may promote organic matter burial and carbon stocks,

33 emphasising the role of coastal basins such as ponds and lagoons as sinks of carbon and their viability for 34 blue carbon areas.

35

36 Key-words: seagrass detritus; litterbag; benthic invertebrate; carbon; nitrogen.

37

38 Highlights

39 - Seagrass decomposition was studied in sites with different hydrodynamic conditions in a coastal 40 basin

41 - Decomposition rate and nutrient release were slower in the site less exposed to the open-sea

42 - Benthic invertebrate density and biomass had their minimum in the site less exposed to the open43 sea

44 - Low decomposition may promote organic matter burial and carbon stocks in low hydrodynamic 45 condition 


\section{Introduction}

Seagrass meadows are ecologically important because of their high primary productivity, provision of habitat and supporting of high biodiversity levels (Hemminga \& Duarte 2000). Seagrasses with mangroves and saltmarshes, trap and sequester carbon, that in the last years has been referred as 'Blue Carbon' (Nellemann et al. 2009). The estimates of organic carbon $\left(\mathrm{C}_{\text {org }}\right)$ sequestered in seagrass meadows, have recognized them as global hotspots in the Blue Carbon global balance (Fourqurean et al. 2012). In the Mediterranean Sea, the endemic species Posidonia oceanica (L.) Delile covers only $1-2 \%$ of the seabed (25,000-50,000 km², Pasqualini et al., 1998), but produces up to 3,499 million tons of carbon annually (Pergent et al. 1997) and represents the largest recognized polls of $C_{o r g}$ stored in living seagrass (Fourqurean et al. 2012). In seagrass meadows, the grazing pathway is highly variable, depending on the study site and time of sampling, with a range between $\sim 3 \%$ and $100 \%$ of net primary production directly consumed by herbivores (Heck \& Valentine 2006 and reference herein). The amount of primary production not directly used becomes litter, which can enter the brown food web or be buried into the sediment (Cebrián \& Duarte 2001, Boudouresque et al. 2015). Therefore, seagrasses act as a significant source of $C_{\text {org }}$ also beyond the area directly occupied by the meadows, through the detrital biomass. Duarte \& Krause-Jensen (2017) pointed out as the potential sequestration of seagrass carbon exported beyond the meadows may approach $30 \%$ of the carbon sequestered within meadows. Detritus act as faunal magnets (Duggins et al. 2016, Remy et al. 2017), attracting fungi and bacteria, but also benthic invertebrates that use them as food and shelter (Heck et al. 2008, Remy et al. 2018). Detritus undergoes decomposition and recycling that allows it to be channeled to higher trophic levels (Michel et al. 2015). The pathway undertaken by detrital leaves is a crucial component of the flow of energy and matter regulated by seagrass meadows (Romero et al. 2006). Despite the recognition of the importance of the detritus, a real estimate of the contribution of this compartment to the Blue carbon global balance is unknown.

Biotic and abiotic variables regulate seagrass decomposition rate (e.g. Enríquez et al., 1993; Mateo and Romero, 1996). Litter quality, such as carbon and nitrogen concentration, influence its decomposition and palatability for consumers (Enríquez et al. 1993, Apostolaki et al. 2009). Abiotic conditions are known to affect decomposition both directly, by influencing rates of biological reactions, and indirectly by modifying leaf quality and/or consumer communities (Nicastro et al. 2012). Among physical variables, the reduced hydrodynamics typical of coastal basins may decrease the mechanical action on the detritus, slowing down the decomposition process, while the increase in nutrients and rise in temperature may stimulate and facilitate the activity of heterotrophic bacteria (Mateo \& Romero 1996, Lopez et al. 1998), accelerating the 
decomposition, but with probably inverse effects at high temperature (Pedersen et al. 2011). Moreover, the high environmental variability of coastal basins, in terms of daily and seasonal variation (Kjerfve 1994), can affect invertebrate community composition. Evolution selects a small number of taxa capable of tolerating this stressful condition, lowering community diversity while abundance and biomass increase (Arias \& Drake 1994, Mistri et al. 2001), with potential consequences for the ecosystem functions. The role of benthic invertebrates as direct detritus shredders and enhancers of microorganism activity is well recognized (Graca 1993), despite invertebrate abundance and decomposition rate are not always positively correlated (Dye 2006), as the macrofauna abundance seem to follow an exponential trend with an upper limit related to the litter quality (Fazi \& Rossi 2000). As the distribution of invertebrates in confined waters, like lagoons and coastal basins, is strongly influenced by water movement (Guelorget \& Perthuisot 1983, Constable 1999), seagrass decomposition rate and therefore nutrients dynamics may respond in the same way.

In this experimental study, we deliberately added $P$. oceanica leaf litter across a gradient of hydrodynamics in a Mediterranean semi-enclosed coastal basin and simultaneously followed the decomposition process, the nutrient dynamics and the colonisation by benthic invertebrates. The specific objectives of the research were (1) to test the null hypothesis of no significant differences of seagrass decomposition and invertebrates colonization across a hydrodynamic gradient; (2) to analyse organic carbon and nitrogen dynamics during seagrass decomposition.

\section{Methods}

\subsection{Study sites and experimental set-up}

The study was conducted in the Stagnone di Marsala, a semi-enclosed coastal basin (surface of $20 \mathrm{~km}^{2}$; average depth of $1 \mathrm{~m}$ ) in western Sicily (Italy) (Fig. 1). The basin is connected to the Mediterranean Sea by a northern and a southern opening, the former narrower and shallower (400 $\mathrm{m}$ wide, 0.3-0.4 $\mathrm{m}$ deep) than the latter (1200 m wide, 1.0-1.5 m deep). The sandy-muddy sediments are colonised by the seagrass Cymodocea nodosa (Ucria) Ascherson. P. oceanica patches are present in the central part of the basin and a natural $P$. oceanica reef emerges in the southern region (Tomasello et al. 2009), creating two geomorphologically different sub-basins. The entire area is oligotrophic (Sarà et al. 1999). Three sites were chosen according to their hydrodynamic regime with the same depth $(0.8 \mathrm{~m})$, vegetation coverage $(C$. nodosa with $P$. oceanica patches) and sediment grain-size (sand $80-90 \%$, silt/clay $5-15 \%$, gravel $0-5 \%$ ): Site

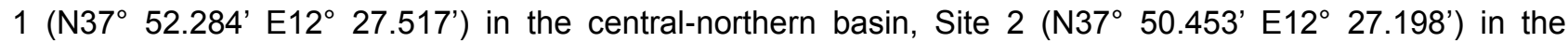
southern basin and Site $3\left(\mathrm{~N}^{\circ} 7^{\circ} 51.613^{\prime} \mathrm{E} 12^{\circ} 26.339^{\prime}\right)$ outside the basin (Fig. 1). The exposure level to the 
open sea in the three sites was obtained from the Intertidal Dispersion Coefficient (IDC, La Loggia et al., 2004). The IDC $\left(\mathrm{m}^{2} \mathrm{~s}^{-1}\right)$ is a useful tool for characterising the dispersion of a point in the water body, integrating data of, among others, water current velocity, wind shear stress and fetches: when the IDC is high, water exchange is strong (hence residence time is short) (Cheng \& Casulli 1992). A clear difference was shown between the central-northern and the southern sub-basins (Fig. 1), with the latter showing higher IDC values (about $23.8 \mathrm{~m}^{2} \mathrm{~s}^{-1}$ ) than the former (about $11.2 \mathrm{~m}^{2} \mathrm{~s}^{-1}$ ) (La Loggia et al. 2004). Since the selected sites were located along a well-documented gradient within the basin, we used the factor Site as a proxy of the hydrodynamic condition of the area.

Seagrass leaves were collected close to P. oceanica patches within the Stagnone di Marsala in May 2010. Adult leaves naturally detached from the plants (due to ageing or mechanical action) were cut into $10 \mathrm{~cm}$ long fragments and only the central section was used, to minimise heterogeneity in thickness and toughness (Mancinelli 2012). Aliquots of leaf fragments were dried at $60^{\circ} \mathrm{C}$ to constant weight, weighed $(3.000 \pm 0.001 \mathrm{~g}$ initial dry mass) and enclosed in $1 \mathrm{~mm}$ mesh litterbags $(10 \times 10 \mathrm{~cm})$. The mesh size of the litterbags was chosen to reduce the amount of detritus lost from mechanical fragmentation but not limiting macroinvertebrates colonization (Walker et al. 2001). Twenty-four litterbags were added to each site and tethered to steel rods anchored to the bottom.

\subsection{Sampling and laboratory procedures}

The litterbags were deployed on June $11^{\text {th }}$ 2010. After 6 hours, three bags per site (time 0) were collected. Remaining bags were collected in triplicate at each site after 3, 7, 14, 47, 101, 152 and 221 days. Each bag was carefully enclosed underwater in a plastic bag and preserved in a cooler for transportation to the laboratory. At each sampling time, temperature (resolution: $\left.\pm 0.01^{\circ} \mathrm{C}\right)$, salinity $( \pm 0.01)$ anddissolved oxygen concentration $\left(\mathrm{DO}, \pm 0.01 \mathrm{mg} \mathrm{l}^{-1}\right.$ ) were measured in the seawater column above the litterbags in triplicate with a HYDROLAB DS5 multiparametric probe.

In the laboratory, litterbags were gently washed and invertebrates inside the litterbags were carefully removed. $P$. oceanica leaf fragments from each bag were dried $\left(60^{\circ} \mathrm{C}, 72 \mathrm{~h}\right)$ and weighed (Dry Mass, DMDM, $\pm 0.001 \mathrm{~g})$. Subsamples were grounded and analysed for organic carbon (C\%) and nitrogen (N\%) concentration using a Flash EA 1112 Thermo-Electron analyser.

Invertebrates were counted and identified at species level. Organisms were dried $\left(60^{\circ} \mathrm{C}, 72 \mathrm{~h}\right)$ and weighed (DM). List of all species identified was included in Table 1.

\subsection{Data elaboration and statistical analysis}


Differences in the mass loss, seagrass leaf litter variables (\%C, \%N and C:N ratio) and density and biomass for each invertebrate group between sites during the experiment were tested via a one-way repeatedmeasures ANOVA (RM-ANOVA): Site (3 levels) was the between-subject factor and Time (i.e. sampling events) the repeated-measures (within-subject) factor.

Decomposition rate was estimated as the loss of dry mass during time and fitted to the exponential curve (Petersen \& Cummins 1974): $W_{t}=W_{0}{ }^{*} e^{-k t}$, where $W_{t}$ is the dry mass $(g)$ remaining at time $t$ (days), $W_{0}$ is the initial dry mass, and $\mathrm{k}$ is the decomposition constant $\left(\mathrm{day}^{-1}\right)$. We used one-way ANOVA with Site (3 levels) as categorical factor to assess the statistical significance of the effect of Site ( 3 levels, $t=221$ days) on decomposition rate.

Prior to ANOVAs, all data were checked for normality and homoscedasticity. In the event of significant effects on the factors investigated, post-hoc comparisons were performed using Tukey's Honest Significant Difference (Zar 1996). Univariate statistical analysis were performed with R version 3.5.1.

Differences in density and biomass of invertebrates species during the experiment were investigated at a multivariate level, through analysis of variance based on permutations (PERMANOVA, Anderson, 2005), using a two-way model with factors Site (3 levels, fixed) and Time (8 levels, random). Data were square-root transformed to build a matrix of Bray-Curtis similarity coefficients. When the number of random permutations in the PERMANOVA analysis was not sufficient to allow a reasonable permutation test, the $p$-value was obtained using a Monte Carlo random sample from the asymptotic permutation distribution (Anderson 2005). The similarity percentage routine (SIMPER) was used to highlight which invertebrate species provided the largest contribution to dissimilarities between groups (Clarke \& Warwick 2001). Multivariate analyses were performed with PRIMER v6 software (Clarke \& Warwick 2001).

\section{Results}

\subsection{Seawater column variables}

Seawater parameters were measured in the water column during the experiment. Temperature showed a clear seasonal trend with a range of $13.3-27.9^{\circ} \mathrm{C}$ and with average higher values at Site 1 than at Site 2 and Site $3\left(23.4 \pm 4.9,22.8 \pm 4.5\right.$ and $22.1 \pm 4.1^{\circ} \mathrm{C}$, respectively). Salinity ranged from 38.0 to 48.0 , with higher values at Site 1 (overall mean: $44.8 \pm 4.0$ ) than at Sites 2 and $3(40.4 \pm 1.4$ and $39.2 \pm 0.7$, respectively). Dissolved oxygen concentration (DO) ranged from 5.5 to $8.9 \mathrm{mg} \mathrm{l}^{-1}$ with the same average value in the three sites $7.3 \pm 0.9 \mathrm{mg} \mathrm{I}^{-1}$.

\subsection{Seagrass leaf litter decomposition}


Seagrass leaf litter decomposition was significantly affected by the factor Site (RM-ANOVA, $F_{2,14}=4.03$, $\mathrm{p}<0.05)$. A rapid mass loss of $P$. oceanica leaf litter was observed at the first sampling date $(0$ days $)$, with an overall mean remaining weight of $2.3 \pm 0.1 \mathrm{~g}$ (mean $\pm \mathrm{s.d}$.) and no differences between sites (Tukey test, $p>0.05)$. More than 60 and $70 \%$ of leaf mass loss occurred after $221 \mathrm{~d}$ in Sites 2 and 3 respectively, compared with a loss of only $40 \%$ in Site 1 (Fig. 2).

Overall, the decomposition process followed an exponential decay, with decomposition rate coefficients ( $k_{221}$ ) significantly higher in Sites $2\left(0.0030 \pm 0.0004\right.$ day $^{-1}, r^{2}$ of the exponential regression line $\left.=0.90\right)$ and 3 $\left(0.0044 \pm 0.0003\right.$ day $\left.^{-1}, r^{2}=0.96\right)$ than in Site $1\left(0.0011 \pm 0.0003\right.$ day $\left.^{-1}, r^{2}=0.60\right)\left(\right.$ ANOVA, $F_{2,6}=76.34$ $\mathrm{p}<0.001$; Tukey test, $\mathrm{p}<0.01)$. No differences were observed between Sites 2 and 3.

\subsection{Seagrass leaf litter features}

Changes in nutrient concentrations (\% $\% \% \mathrm{~N}$ and $\mathrm{C}: \mathrm{N}$ ratio) were observed in seagrass leaf litter during the experiment (Fig. 3). Despite the hydrodynamic condition did not affect $\mathrm{C}$ concentration of the detritus during the decomposition (RM-ANOVA, $F_{2,14}=1.89, p>0.05$ ), the overall initial $\mathrm{C}$ concentration (average $38.2 \%$ ) decreased slightly, and at day 221 a lower C concentration was recorded at Site $3(33.2 \pm 0.3 \%)$ than at Sites 1 and 2 (37.1 \pm 0.7 and $35.0 \pm 1.1 \%$, respectively) (Fig. 3; Tukey test, $\mathrm{p}<0.01)$. N concentration showed a very narrow range of variation from $0.8 \pm 0.1 \%$ (Site 1,101 days) to $1.3 \pm 0.2 \%$ (Site 2,152 days) with no significant differences between sites during the experiment (RM-ANOVA, $\left.F_{2,14}=3.48, p>0.05\right)$. C: $N$ ratio ranged from $29.1 \pm 5.1$ (Site 2, 152 days) to $49.0 \pm 4.0$ (Site 1, 101 days) with significant differences between sites during the experiment (RM-ANOVA, $\left.\mathrm{F}_{2,14}=5.24, \mathrm{p}<0.05\right)$. At the beginning of the experiment $\mathrm{C}: \mathrm{N}$ ratio averaged 35.5 while at the end higher values were recorded at Site 1 than at Sites 2 and 3 (39.2 $\pm 1.8,32.8$ \pm 1.9 and $32.1 \pm 2.7$, respectively) (Fig. 3; Tukey test, $p<0.05)$

\subsection{Invertebrate densities and biomass}

A total of 1964 individuals (379, 948 and 637 respectively at Site 1, 2 and 3) belonging to 3 Phyla were recovered and identified: the Arthropoda was the phylum with the highest number of taxa (46 crustacean species grouped in 3 orders, 40 species of Amphipoda, 4 species of Isopoda and 2 species of Tanaidacea), followed by Mollusca ( 8 species grouped in 2 classes, 1 species of Bivalvia and 7 species of Gastropoda) and Anellida (2 species belonging to Polychaeta class) (Tab. 1).

Density and biomass of the entire invertebrate community were significantly affected by the interaction Site $\mathrm{x}$ Time (PERMANOVA, Tab. 2). Pairwise tests for the term Site $x$ Time for Site factor showed significant differences from 47 to 152 days, with Site 1 showing significantly lower values than the others $(P(M C)$ 
$<0.05)$. In general, the average dissimilarity, in terms of density and biomass data, was always higher between Site 1 and the others than between Sites 2 and 3 (SIMPER; Tab. 3). The invertebrate groups mostly responsible for differences between sites belong to the Arthropoda for both density and biomass data: the amphipod Gammarus aequicauda (Martynov, 1931) contributes always for more than $10 \%$ and $7 \%$ to this dissimilarity, respectively for density and biomass data, followed by the tanaidacean Chondrochelia savignyi (Krøyer, 1842), and the caprellid Caprella acanthifera (Leach, 1814) for density data and the isopod Cymodoce truncate (Leach, 1814), the polychaetes Nereis sp. and the amphipod Lysianassa caesarea for biomass data. (Tab. 3). Other species generally contributed less than $8 \%$ to the average dissimilarity between sites (Tab. 3).

Colonization of litterbags started with the Gastropoda Tricolia pullus at Site 1 (day 0), while at 3 days with Amphipoda [G. aequicauda and Melita palmata (Montagu, 1804)], Isopoda (C. truncate) and Tanaidacea (C. savignyi) and Amphipoda [Aora gracilis (Bate, 1857), C. acanthifera, G. aequicauda, Lysianassa costae (Milne Edwards, 1830), Pseudoprotella phasma (Montagu, 1804)], Tanaidacea (L. savignyI) and Gastropoda [Melarhaphe neritoides (Linnaeus, 1758)], respectively at Sites 2 and 3 (Fig. 4). Total density ranged from 0.1 \pm 0.2 to $13.4 \pm 6.3$ (Site 1,0 and 101 days), from 0.0 to $77.8 \pm 27.9$ (Site 2, 0 and 101 days) and from 0.0 to $49.8 \pm 18.5$ (Site 3,0 and 152 days) individuals $\mathrm{g}^{-1}$ DM of seagrass detritus (Fig. 4). Total biomass ranged from $0.2 \pm 0.3$ to $4.7 \pm 0.9$, from 0.0 to $30.7 \pm 33.7$ and from 0.0 to $22.4 \pm 15.2 \mathrm{mg} \mathrm{g}^{-1} \mathrm{DM}$ respectively at Site 1,2 and 3 ( 0 and 221 days) (Fig. 5). Univariate analysis showed that the density of organisms changed during the experiment, with significant differences between sites only for the Amphipoda group (RM-ANOVA, $F_{2,14}=3.97, p<0.05$ ) (Fig. 4), while no significant differences in biomass data were reported (RM-ANOVA, p >0.05) (Fig. 5)

The invertebrate community was dominated by the Arthropoda both in terms of density (up to $106 \mathrm{ind}^{-1}$ DM) and biomass (up to $65 \mathrm{mg} \mathrm{g}^{-1} \mathrm{DM}$ ): Amphipoda density and biomass increased gradually reaching the maximum at the end of the experiment at Site 2 (Figs. 4, 5); Isopoda showed the highest density at 101 days at Site 2, while Tanaidacea showed the highest density and biomass at 101 days at Site 3 (Fig. 4, 5). Density for Anellida was always below 8 ind. $\mathrm{g}^{-1} \mathrm{DM}$, with the highest values of density and biomass at Site 3 at the end of the experiment (Fig. 4,5). Mollusca Bivalvia showed no changes during the experiment in terms of density and biomass, while Gastropoda density showed high values at 101 days and the highest biomass at the end of the experiment at Site 3 (Fig. 4, 5).

\section{Discussion}




\subsection{Seagrass leaf litter decomposition and nutrient dynamics}

Seagrass meadows are recognized as some of the most productive of the Earth's ecosystems (Fourqurean et al. 2012), but most of the primary production is exploited only through detrital routes (Cebrián \& Duarte 2001). Accordingly, in the Stagnone di Marsala, the bottom of which is covered by a dense $C$. nodosa meadow and patchy $P$. oceanica, there is evidence for the role of seagrass-derived organic matter for consumers through detrital pathways (Vizzini et al. 2013).

In this area, leaf litter decomposition rates (from 0.001 to 0.004 day $^{-1}$ ) were in the range reported for seagrasses (from 0.001 to 0.110 day $^{-1}$; Harrison, 1989), despite the decomposition rate recorded for the central part of the Stagnone was lower than previously observed values for P. oceanica (from 0.003 to 0.017 day $^{-1}$; Romero et al. 1992, Mateo \& Romero 1996, Cebrián et al. 1997). The high variability of seagrass decomposition rates reported in the literature may be ascribed to the different experimental conditions in decomposition studies. As summarised by Harrison (1989), the length of the study (from days to years), the use of different types of detritus (fresh or dried leaves), leaf age (green leaves lose mass faster than old ones) and also the mesh size (smaller mesh reduce the amount of particles lost but affect colonization) are among the conditions that may affect the decay rates. Leaf litter decomposition rates in this study exhibited a high spatial heterogeneity that was not imputable to the experimental conditions (i.e. type of detritus, leaf age), which were homogeneous at the beginning of the experiment. The $P$. oceanica decomposition rate was $2 x$ and $4 x$ higher respectively in the southern and in the external sites than in the central-northern site. Despite, the low decomposition rate in the Site 1 could be ascribed to different experimental conditions compared to other studies, this result highlights a clear spatial pattern in the decomposition dynamics within the basin.

Based on $\mathrm{C}$ and $\mathrm{N}$ concentration in seagrass leaf litter, loss of organic nutrients from the detritus on a daily basis was calculated as the total mass $\mathrm{x}$ nutrient concentration at the beginning of the experiment minus that at the end divided by the number of experimental days (Wardle et al. 2002). Carbon release rates were 0.09 $\pm 0.01,0.21 \pm 0.01$ and $0.26 \pm 0.01 \mathrm{mgC} \mathrm{g}^{-1} \mathrm{~d}^{-1}$ in Sites 1,2 and 3 respectively, showing the same spatial pattern as for litter decomposition rates, with a higher loss outside the basin than in the internal sites. In contrast, nitrogen released by seagrass detritus was constant at all sites $\left(0.01 \pm 0.00 \mathrm{mgN} \mathrm{g}^{-1} \mathrm{~d}^{-1}\right)$.

Leaf detritus is a source of nutrients which return in soluble forms through decomposition (Harrison 1989, Romero et al. 2006), but the dynamics of carbon and nitrogen regeneration during the decay process is rather complex and, as suggested in the literature, there is no common pattern to nutrient loss (see references in Romero et al., 2006), highlighting the uncoupling between nutrient release and the negative 
exponential trend of mass loss (Petersen \& Cummins 1974). As summarised in Romero et al. (2006), during the first phase of decomposition (leaching), the labile components release nutrients that can be assimilated by microbes colonising the detritus; when all the labile substrates are processed, nutrients from the dead leaf tissues are released in inorganic and/or organic forms (which can be assimilated again by microbes) by means of bacteria exoenzyme attack; during the last phase of decomposition, the refractory portion decomposes very slowly, releasing only nitrogen, while most of the carbon remains (Kristensen 1994).

These expected dynamics of nutrients were partially matched in our study: the initial phase of labile nutrient release was probably bypassed by the pre-drying treatment of leaf litter as organic molecules become less easily degraded (Harrison 1989); the slow release of C (from $\sim 38 \%$ to $\sim 33 \%$ ) was coupled with the stable condition reported for the $\mathrm{N}$ concentration (from $\sim 1.3 \%$ to $\sim 0.8 \%$ ), with the decrease of $\mathrm{C}$ related to the decomposition of mobilizable carbohydrates, and the stable $\mathrm{N}$ values probably related to the accumulation of microbial biomass that can be responsible for a high portion $(75-100 \%)$ of the total nitrogen content in decaying litter (Newell 1996). In addition, the slower loss of organic matter was previously reported for dead leaves (used in this study) compared to fresh material (Harrison \& Mann 1975) This dynamic of nutrient release also explains the fact that the C:N ratio of detritus was remarkably high, exhibiting a wide range of variation from $\sim 30$ to $\sim 50$, but was within the range reported for seagrass detritus (14-75; Enríquez et al., 1993). Moreover, the higher C:N reported for the internal site during the experiment indicates that seagrass detritus here becomes more recalcitrant to decomposition (Pirc \& Wollenweber 1988) and more refractory to digestion by consumers than in the other sites. Accordingly, the seagrass-derived organic matter largely contributes to the sedimentary organic matter pool in the central part of the Stagnone di Marsala, as shown by stable isotope data (Vizzini et al. 2013), pinpointing the role of the basin as a sink of organic carbon.

\subsection{Role of invertebrate community in seagrass leaf litter decomposition}

Leaf litter, as a particular benthic substrate, provides food to invertebrates and refuge from predators, channelling marine macrophyte production to higher trophic levels through the detritus-based food web (Lepoint et al. 2006). Most of the invertebrates living in P. oceanica detritus belong to the typical community found in the meadows (Gambi et al. 1992, Sánchez-Jerez et al. 1999), despite the fact that some species show specific adaptations to the detritus habitat (e.g. different body colouration for the isopod Idotea sp. and the shrimp Hyppolyte inermis, Gallmetzer et al., 2005).

Despite the limitation due to the mesh size of the litterbags, colonization of the detritus by invertebrates is generally a rapid process (Norkko \& Bonsdorff 1996), as also shown in our study (overall colonization started after three days), with the dominance of motile taxa (e.g. amphipods, isopods and tanaidaceans). During the 
experiment, Amphipoda and Isopoda were responsible for among-site differences in the invertebrate assemblages both in terms of density and biomass. The dominance of crustaceans in detritus accumulation is well-documented (Gallmetzer et al. 2005), with amphipods and isopods being the main constituents of the crustacean community of $P$. oceanica detritus (Wittmann et al. 1981, Remy et al. 2018). Crustaceans, and in particular amphipods and isopods, are an abundant, widely distributed and ecologically important component of benthic communities, exhibiting a high degree of niche specificity (Mancinelli \& Rossi 2002, De-La-OssaCarretero et al. 2012). In our study, G. aequicauda was responsible for among-site differences in the macrofaunal assemblages both in term of densities and biomass. Within the amphipods, the Gammarus genus is a highly opportunistic feeder group (defined as a facultative shredder by Cummins and Klug, 1979), but with a certain degree of selectivity probably related to environmental characteristics (Friberg \& Jacobsen 1994, Mancinelli \& Rossi 2002). Based on stable isotope and/or gut content analysis, some species were reported to directly feed on $P$. oceanica leaf litter within these species the amphipods G. aequicauda and Gammarella fucicola (Remy et al. 2018), but also isopods of the genera Idotea and Cleantis (Lepoint et al. 2006, Sturaro et al. 2010) and some echinoderms as the holothurian Holothuria tubulosa Gmelin (Costa et al. 2014). In particular, G. aequicauda relied up to $80 \%$ of its diet on $P$. oceanica leaf detritus(Michel et al. 2015, Remy et al. 2018), highlighting the crucial role of this species not only during the fragmentation process but also in the transfer of seagrass detritus organic matter in the food chain.

Low density and biomass of the invertebrate community were recorded in the central part of the Stagnone di Marsala, where carbon released by detritus was lower, seagrass detritus more recalcitrant (high $\mathrm{C}: \mathrm{N}$ ratios) and resistant to degradation (Enríquez et al. 1993) and, hence, the decomposition rate was reduced. The central part of the Stagnone is characterised by reduced hydrodynamic condition (La Loggia et al. 2004), which may influence seagrass decomposition both directly and indirectly. Hydrodynamic is known to contribute to detritus fragmentation through direct mechanical action on seagrass leaves, increasing the surface available for microbial colonization (Mateo \& Romero 1997, Romero et al. 2006). Moreover, reduced hydrodynamic could act not only limiting the loss of fine particles through the litterbag but also reducing the aeration of the litter through water movement in very shallow basins is also responsible for wide variability in seawater variables which, in combination with the poor nutritional value of detritus, may have limited invertebrate (but also microbial) colonization and slowed down the decomposition process.

\section{Conclusions}


Seagrass decomposition rate varied at a small spatial scale in a semi-enclosed coastal basin, resulting faster in the sites that are more exposed to the open-sea than in the internal part of the Stagnone di Marsala. The Stagnone seems to act as a sink of organic matter wherein the slow recycling process enhances the accumulation of refractory materials. Moreover, the peculiar environmental characteristics of the internal site constrain invertebrate abundance and the more recalcitrant and refractory condition of the detritus results in slower decomposition. Consequently, low decomposition rates of seagrass leaves in internal sites characterised by low hydrodynamic forces may promote organic matter burial and carbon stocks, emphasising the role of coastal basins such as ponds and lagoons as blue carbon areas (Nellemann et al. 2009).

\section{References}

Anderson MJ (2005) PERMANOVA: a FORTRAN computer program for permutational multivariate analysis of variance. Department of Statistics, University of Auckland, New Zealand

Apostolaki ET, Marbà N, Holmer M, Karakassis I (2009) Fish farming impact on decomposition of Posidonia oceanica litter. J Exp Mar Bio Ecol 369:58-64

Arias AM, Drake P (1994) Structure and production of the benthic macroinvertebrate community in a shallow lagoon in the Bay of Cadiz. Mar Ecol Prog Ser 115:151-167

Boudouresque CF, Pergent G, Pergent-Martini C, Ruitton S, Thibaut T, Verlaque M (2015) The necromass of the Posidonia oceanica seagrass meadow: fate, role, ecosystem services and vulnerability. Hydrobiologia 781:1-18

Cebrián J, Duarte CM (2001) Detrital stocks and dynamics of the seagrass Posidonia oceanica (L.) Delile in the Spanish Mediterranean. Aquat Bot 70:295-309

Cebrián J, Duarte CM, Marbà NN, Enríquez S (1997) Magnitude and fate of the production of four cooccurring Western Mediterranean seagrass species. Mar Ecol Prog Ser 155:29-44

Cheng RT, Casulli V (1992) Dispersion in tidally averaged transport equation. In: Prandle D (ed) Dynamics and exchanges in estuaries and the coastal zone. American Geophysical Union, Washington, D.C., p 409-428

Clarke KR, Warwick RM (2001) Change in marine communities: an approach to statistical analysis and interpretation. Prim Plymouth UK:172 p

Constable AJ (1999) Ecology of benthic macro-invertebrates in soft-sediment environments: A review of progress towards quantitative models and predictions. Austral Ecol 24:452-476 
Costa V, Mazzola A, Vizzini S (2014) Holothuria tubulosa Gmelin 1791 (Holothuroidea, Echinodermata) enhances organic matter recycling in Posidonia oceanica meadows. J Exp Mar Bio Ecol 461:226-232

Cummins K, Klug M (1979) Feeding ecology of stream invertebrates. Annu Rev Ecol Syst

De-La-Ossa-Carretero JA, Del-Pilar-Ruso Y, Giménez-Casalduero F, Sánchez-Lizaso JL, Dauvin J-CC (2012) Sensitivity of amphipods to sewage pollution. Estuar Coast Shelf Sci 96:129-138

Duarte CM, Krause-Jensen D (2017) Export from Seagrass Meadows Contributes to Marine Carbon Sequestration. Front Mar Sci 4:13

Duggins DO, Gómez-Buckley MC, Buckley RM, Lowe AT, Galloway AWE, Dethier MN (2016) Islands in the stream: kelp detritus as faunal magnets. Mar Biol 163:1-10

Dye AH (2006) Inhibition of the decomposition of Zostera capricornii litter by macrobenthos and meiobenthos in a brackish coastal lake system. Estuaries and Coasts 29:802-809

Enríquez S, Duarte CM, Sand-Jensen K, Enriquez S (1993) Patterns in decomposition rates among photosynthetic organisms: the importance of detritus C:N:P content. Oecologia 94:457-471

Fazi S, Rossi L (2000) Effects of macro-detritivores density on leaf detritus processing rate: a macrocosm experiment. Hydrobiologia 435:127-134

Fourqurean JW, Duarte CM, Kennedy H, Marbà N, Holmer M, Mateo MÁ, Apostolaki ET, Kendrick GA, Krause-Jensen D, McGlathery KJ, Serrano O (2012) Seagrass ecosystems as a globally significant carbon stock. Nat Geosci 5:505-509

Friberg N, Jacobsen D (1994) Feeding plasticity of two detritivore-shredders. Freshw Biol 32:133-142

Gallmetzer I, Pflugfelder-Plank B, Zekely J, Ott JA, Pflugfelder B, Zekely J, Ott JA (2005) Macrofauna diversity in Posidonia oceanica detritus: distribution and diversity of mobile macrofauna in shallow sublittoral accumulations of Posidonia oceanica detritus. Mar Biol 147:517-523

Gambi MC, Lorenti M, Russo GF, Scipione MB, Zupo V (1992) Depth and Seasonal Distribution of Some Groups of the Vagile Fauna of the Posidonia oceanica Leaf Stratum: Structural and Trophic Analyses. Mar Ecol 13:17-39

Graca MAS (1993) Patterns and processes in detritus-based stream systems. Limnologica 23:107-114

Guelorget O, Perthuisot JP (1983) Le domaine paralique: expressions géologiques, biologiques et économiques du confinement.

Harrison PG (1989) Detrital processing in seagrass systems: A review of factors affecting decay rates, remineralization and detritivory. Aquat Bot 35:263-288

Harrison PG, Mann KH (1975) Detritus formation from eelgrass (Zostera marina L.): The relative effects of 
fragmentation, leaching, and decay. Limnol Oceanogr 20:924-934

Heck KL, Carruthers TJB, Duarte CM, Hughes a R, Kendrick G a, Orth RJ, Williams SWSW, Jr KLH, Randall A (2008) Trophic Transfers from Seagrass Meadows Subsidize Diverse Marine and Terrestrial Consumers. Ecosystems 11:1198-1210

Heck KL, Valentine JF (2006) Plant-herbivore interactions in seagrass meadows. J Exp Mar Bio Ecol $330: 420-436$

Hemminga MA, Duarte CM (2000) Seagrass ecology. Cambridge University Press

Kjerfve B (1994) Coastal lagoon processes. Elsevier, Amsterdam

Kristensen E (1994) Decomposition of macroalgae, vascular plants and sediment detritus in seawater: Use of stepwise thermogravimetry. Biogeochemistry $26: 1-24$

Lepoint G, Cox A-S, Dauby P, Poulicek M, Gobert S (2006) Food sources of two detritivore amphipods associated with the seagrass Posidonia oceanica leaf litter. Mar Biol Res 2:355-365

Loggia G La, Calvo S, Ciraolo G, Mazzola A, Pirrotta M, Sarà G, Tomasello A, Vizzini S (2004) Influence of hydrodynamic conditions on the production and fate of Posidonia oceanica in a semi-enclosed shallow basin (Stagnone di Marsala, Western Sicily). Chem Ecol 20:183-201

Lopez NI, Duarte CM, Vallespinos F, Romero J, Alcoverro T (1998) The effect of nutrient additions on bacterial activity in seagrass (Posidonia oceanica) sediments. J Exp Mar Bio Ecol 224:155-166

Mancinelli G (2012) To bite, or not to bite? A quantitative comparison of foraging strategies among three brackish crustaceans feeding on leaf litters. Estuar Coast Shelf Sci 110:125-133

Mancinelli G, Rossi L (2002) The Influence of Allochthonous Leaf Detritus on the Occurrence of Crustacean Detritivores in the Soft-bottom Macrobenthos of the Po River Delta Area (northwestern Adriatic Sea). Estuar Coast Shelf Sci 54:849-861

Mateo MÁ, Romero J (1996) Evaluating seagrass leaf litter decomposition: an experimental comparison between litter-bag and oxygen-uptake methods. J Exp Mar Bio Ecol 202:97-106

Mateo MÁ, Romero J (1997) Detritus dynamics in the seagrass Posidonia oceanica: elements for an ecosystem carbon and nutrient budget. Mar Ecol Prog Ser 151:43-53

Michel LN, Dauby P, Gobert S, Graeve M, Nyssen F, Thelen N, Lepoint G (2015) Dominant amphipods of Posidonia oceanica seagrass meadows display considerable trophic diversity. Mar Ecol 36:969-981

Mistri M, Fano EA, Rossi R (2001) Redundancy of macrobenthos from lagoonal habitats in the Adriatic Sea. Mar Ecol Prog Ser 215:289-296

Nellemann C, Corcoran E, Duarte CM, Valdes L, DeYoung C, Fonseca L, Grimsditch GD (2009) Blue carbon: 
the role of healthy oceans in binding carbon: a rapid response assessment (Birkeland Trykkeri AS Norway, Ed.). United Nations Environment Programme, GRID-Arendal

Newell SY (1996) Established and potential impacts of eukaryotic mycelial decomposers in marine/terrestrial ecotones. J Exp Mar Bio Ecol 200:187-206

Nicastro A, Onoda Y, Bishop M (2012) Direct and indirect effects of tidal elevation on eelgrass decomposition. Mar Ecol Prog Ser

Norkko A, Bonsdorff E (1996) Rapid zoobenthic community responses to accumulations of drifting algae. Mar Ecol Prog Ser 131:143-157

Pasqualini V, Pergent-Martini C, Clabaut P, Pergent G (1998) Mapping of Posidonia oceanica using aerial photographs and side scan sonar: application off the island of Corsica (France). Estuar Coast Shelf Sci 47:359-367

Pedersen M, Serrano O, Mateo M, Holmer M (2011) Temperature effects on decomposition of a Posidonia oceanica mat. Aquat Microb Ecol 65:169-182

Pergent G, Rico-Raimondino V, Pergent-Martini C (1997) Fate of primary production in Posidonia oceanica meadows of the Mediterranean. Aquat Bot 59:307-321

Petersen RC, Cummins KW (1974) Leaf processing in a woodland stream. Freshw Biol 4:343-368

Pirc H, Wollenweber B (1988) Seasonal Changes in Nitrogen, Free Amino Acids, and C/N Ratio in Mediterranean Seagrasses. Mar Ecol 9:167-179

Remy F, Gobert S, Lepoint G (2017) Effects of an experimental resource pulse on the macrofaunal assemblage inhabiting seagrass macrophytodetritus. Belgian J Zool 147:1-15

Remy F, Mascart T, Troch M De, Loïc MN, Lepoint G (2018) Seagrass organic matter transfer in Posidonia oceanica macrophytodetritus accumulations. Estuar Coast Shelf Sci 212:73-79

Romero J, Lee K, Pérez M, Mateo MÁ, Alcoverro T (2006) Nutrient dynamics in seagrass ecosystems. In: Larkum AWD, Orth RJ, Duarte CM (eds) Seagrasses: Biology, Ecology and Conservation. Springer, p $227-254$

Romero J, Pergent G, Pergent-Martini C, Mateo MÁ, Regnier C (1992) The Detritic Compartment in a Posidonia oceanica Meadow: Litter Features, Decomposition Rates, and Mineral Stocks. Mar Ecol 13:69-83

Sánchez-Jerez P, Cebrian CB, Ramos Espla AA (1999) Comparison of the epifauna spatial distribution in Posidonia oceanica, Cymodocea nodosa and unvegetated bottoms: Importance of meadow edges. Acta Oecologica 20:391-405 
448 Sarà G, Leonardi M, Mazzola A (1999) Spatial and temporal changes of suspended matter in relation to wind and vegetation cover in a Mediterranean shallow coastal environment. Chem Ecol 16:151-173

Sturaro N, Caut S, Gobert S, Bouquegneau JM, Lepoint G (2010) Trophic diversity of idoteids (Crustacea, Isopoda) inhabiting the Posidonia oceanica litter. Mar Biol 157:237-247

Tomasello A, Maida G Di, Calvo S, Pirrotta M, Borra M, Procaccini G (2009) Seagrass meadows at the extreme of environmental tolerance: the case of Posidonia oceanica in a semi-enclosed coastal lagoon. Mar Ecol 30:288-300

Vizzini S, Costa V, Tramati CD, Gianguzza P, Mazzola A (2013) Trophic transfer of trace elements in an isotopically constructed food chain from a semi-enclosed marine coastal area (Stagnone di Marsala, Sicily, Mediterranean). Arch Environ Contam Toxicol 65:642-53

Walker DI, Pergent G, Fazi S (2001) Seagrass decomposition. In: Short FT, Coles RG (eds) Global Seagrass Research Methods. Elsevier B.V, p 1-12

Wardle DA, Bonner KI, Barker GM (2002) Linkages between plant litter decomposition, litter quality, and vegetation responses to herbivores. Funct Ecol 16:585-595

Wittmann K, Scipione MB, Fresi E, Wittman K, Scipione MB, Fresi E (1981) Some laboratory experiments on the activity of the macrofauna in the fragmentation of detrital leaves of Posidonia oceanica (L.) Delile. Rapp la Comm Int pour l'Exploration la mer Mèditerranèe 27:205-206

Zar JH (1996) Biostatistical analysis, 3rd edn. Prentice-Hall, Prentice-Hall, Englewood Cliffs, NJ, USA 
Table 1. List of all taxa identified in the three sites: Site 1 , Site 2 and Site $3(* /:$ presence/absence).

\begin{tabular}{|c|c|c|c|c|}
\hline & TAXA & & SITE & \\
\hline & THA & 1 & 2 & 3 \\
\hline Anellida & & & & \\
\hline Polychaeta & Nereis sp. & $*$ & & $*$ \\
\hline & Terebella sp. & & $*$ & $*$ \\
\hline Arthropoda & & & & \\
\hline Amphipoda & Amphilochus sp. & $*$ & & \\
\hline & Aora gracilis & & $*$ & * \\
\hline & Aora sp. & $*$ & & \\
\hline & Aora spinicornis & & & $*$ \\
\hline & Autonoe rubromaculatus & $*$ & $*$ & \\
\hline & Autonoe viduarum & $*$ & $*$ & \\
\hline & Caprella acanthifera & $*$ & $*$ & $*$ \\
\hline & Elasmopus brasiliensis & & $*$ & $*$ \\
\hline & Elasmopus pectenicrus & & $*$ & $*$ \\
\hline & Elasmopus pocillimanus & & $*$ & $*$ \\
\hline & Elasmopus rapax & & $*$ & $*$ \\
\hline & Elasmopus sp. & $*$ & $*$ & * \\
\hline & Ericthonius punctatus & & $*$ & $*$ \\
\hline & Gammarella fucicola & $*$ & $*$ & * \\
\hline & Gammarus aequicauda & $*$ & $*$ & $*$ \\
\hline & Idunella pirata & $*$ & & \\
\hline & Lembos sp. & & $*$ & * \\
\hline & Lembos websteri & $*$ & $*$ & \\
\hline & Leptocheirus bispinosus & $*$ & $*$ & * \\
\hline & Leptocheirus mariae & & & $*$ \\
\hline & Lysianassa caesarea & * & $*$ & * \\
\hline & Lysianassa costae & $*$ & $*$ & * \\
\hline & Lysianassa sp. & $*$ & $*$ & $*$ \\
\hline & Maera grossimana & $*$ & $*$ & $*$ \\
\hline & Maera hirondellei & $*$ & $*$ & $*$ \\
\hline & Maera pachytelson & & $*$ & \\
\hline & Maera sodalis & $*$ & $*$ & $*$ \\
\hline & Maera sp. & $*$ & $*$ & $*$ \\
\hline & Melita bulla & & $*$ & $*$ \\
\hline & Melita hergensis & & * & $*$ \\
\hline & Melita palmata & $*$ & $*$ & \\
\hline & Melita sp. & & $*$ & \\
\hline & Microdeutopus bifidus & & $*$ & \\
\hline & Microdeutopus chelifer & $*$ & $*$ & \\
\hline & Microdeutopus similis & & $*$ & \\
\hline & Microdeutopus sp. & $*$ & $*$ & \\
\hline & Microdeutopus stationis & $*$ & $*$ & \\
\hline & Orchomene grimaldii & & $*$ & \\
\hline & Pseudoprotella phasma & & & $*$ \\
\hline & Quadrimaera inaequipes & $*$ & $*$ & $*$ \\
\hline Isopoda & Anthura sp. & & $*$ & * \\
\hline & Cymodoce truncata & $*$ & $*$ & $*$ \\
\hline & Gnathia phallonajopsis & & $*$ & $*$ \\
\hline & Joeropsis brevicornis & & $*$ & $*$ \\
\hline Tanaidacea & Apseudopsis latreillii & & & $*$ \\
\hline & Chondrochelia savignyi & $*$ & $*$ & $*$ \\
\hline Mollusca & & & & \\
\hline Bivalvia & Cerastoderma glaucum & $*$ & & $*$ \\
\hline Gastropoda & Cerithium sp. & $*$ & $*$ & $*$ \\
\hline & Eucithara sp. & & $*$ & \\
\hline & Gibbula sp. & $*$ & & $*$ \\
\hline & Haminoea hydatis & $*$ & $*$ & * \\
\hline & Melarhaphe neritoides & & & * \\
\hline & Rissoa sp. & * & $*$ & \\
\hline & Tricolia pullus & $*$ & & $*$ \\
\hline
\end{tabular}


469 Table 2. PERMANOVA results for the effects of factors Site and Time on density (individuals $\mathrm{g}^{-1} \mathrm{DM}$ of

470 seagrass detritus) and biomass ( $\mathrm{mg} \mathrm{g}^{-1} \mathrm{DM}$ of seagrass detritus) of the invertebrate community. n.s.: $\mathrm{p}>0.05$;

$471 \quad$ *: $p \leq 0.05 ;{ }^{* *}: p \leq 0.01 ;{ }^{* * *}: p \leq 0.001$.

\begin{tabular}{|c|c|c|c|c|c|c|c|}
\hline \multirow[b]{2}{*}{ Source } & \multirow[b]{2}{*}{$d f$} & \multicolumn{3}{|c|}{ Density (ind. $\mathrm{g}^{-1} \mathrm{DM}$ ) } & \multicolumn{3}{|c|}{ Biomass (ind. $\mathrm{g}^{-1} \mathrm{DM}$ ) } \\
\hline & & MS & Pseudo-F & $\boldsymbol{P}$ & MS & Pseudo-F & $\boldsymbol{P}$ \\
\hline Site & 2 & 8082.80 & 6.34 & $* * *$ & 9545.80 & 4.86 & *** \\
\hline Time & 6 & 9283.40 & 7.28 & $* * *$ & 9982.30 & 5.09 & *** \\
\hline Site*Time & 12 & 2493.50 & 1.96 & $* * *$ & 3198.10 & 1.63 & *** \\
\hline Residuals & 42 & 1275.10 & & & 1963.10 & & \\
\hline
\end{tabular}


473 Table 3. Results of the SIMPER analysis on density (ind. $\mathrm{g}^{-1} \mathrm{DM}$ ) and biomass ( $\mathrm{mg} \mathrm{g}^{-1} \mathrm{DM}$ ) data showing the 474 contribution of invertebrate species to dissimilarity between sites during the experiment: $A D / S D$, ratio of the 475 average dissimilarity to the standard deviation of dissimilarity for the particular species; Contr(\%), percentage 476 contribution to the dissimilarity. Cut-off: cumulative percentage $60 \%$.

477

\begin{tabular}{|c|c|c|c|c|c|c|c|}
\hline \multicolumn{4}{|c|}{ Density (ind. $\mathrm{g}^{-1} \mathrm{DM}$ ) } & \multicolumn{4}{|c|}{ Biomass (ind. $\mathrm{g}^{-1} \mathrm{DM}$ ) } \\
\hline Species & $\begin{array}{c}\text { Average } \\
\text { Dissimilarity }\end{array}$ & AD/SD & Contr(\%) & Species & $\begin{array}{c}\text { Average } \\
\text { Dissimilarity }\end{array}$ & AD/SD & Contr(\%) \\
\hline Site 1 vs 2 & 65.59 & & & Site 1 vs 2 & 74.39 & & \\
\hline Gammarus aequicauda & & 0.91 & 13.29 & Gammarus aequicauda & & 0.69 & 9.12 \\
\hline Chondrochelia savignyi & & 1.04 & 9.2 & Cymodoce truncata & & 0.57 & 7.34 \\
\hline Joeropsis brevicornis & & 0.93 & 8.15 & Lysianassa caesarea & & 0.7 & 7.31 \\
\hline Gnathia phallonajopsis & & 0.63 & 7.97 & Nereis sp. & & 0.82 & 6.79 \\
\hline Tricolia pullus & & 0.22 & 6.93 & Tricolia pullus & & 0.22 & 6.11 \\
\hline Caprella acanthifera & & 0.64 & 6.92 & Chondrochelia savignyi & & 0.63 & 5.75 \\
\hline \multirow{3}{*}{ Maera sodalis } & & 0.74 & 5.51 & Caprella acanthifera & & 0.58 & 5.37 \\
\hline & & & & Gnathia phallonajopsis & & 0.73 & 5.26 \\
\hline & & & & Maera sodalis & & 0.7 & 5.22 \\
\hline Site 1 vs 3 & 63.38 & & & Site 1 vs 3 & 74.38 & & \\
\hline Gammarus aequicauda & & 0.74 & 12.19 & Gammarus aequicauda & & 0.63 & 9.26 \\
\hline Chondrochelia savignyi & & 1.29 & 11.78 & Nereis sp. & & 0.82 & 8.09 \\
\hline Tricolia pullus & & 0.23 & 7.54 & Tricolia pullus & & 0.25 & 6.97 \\
\hline Caprella acanthifera & & 0.56 & 7.11 & Maera sodalis & & 0.64 & 6.56 \\
\hline Maera sodalis & & 0.71 & 5.94 & Caprella acanthifera & & 0.59 & 5.93 \\
\hline Nereis sp. & & 0.85 & 5.22 & Lysianassa costae & & 0.74 & 5.39 \\
\hline Lysianassa costae & & 0.77 & 4.72 & Quadrimaera inaequipes & & 0.61 & 5.17 \\
\hline \multirow[t]{2}{*}{ Quadrimaera inaequipes } & & 0.64 & 4.6 & Chondrochelia savignyi & & 0.66 & 5.08 \\
\hline & & & & Lysianassa caesarea & & 0.52 & 4.07 \\
\hline Site 2 vs 3 & 54.07 & & & Site 2 vs 3 & 68.4 & & \\
\hline Gammarus aequicauda & & 1.1 & 10.43 & Gammarus aequicauda & & 0.89 & 7.93 \\
\hline Caprella acanthifera & & 0.62 & 8.41 & Lysianassa caesarea & & 0.65 & 7.32 \\
\hline Gnathia phallonajopsis & & 0.69 & 8.27 & Cymodoce truncata & & 0.57 & 6.52 \\
\hline Joeropsis brevicornis & & 1.02 & 7.95 & Caprella acanthifera & & 0.63 & 5.79 \\
\hline Chondrochelia savignyi & & 0.95 & 7.94 & Gnathia phallonajopsis & & 0.73 & 5.34 \\
\hline Lysianassa costae & & 0.73 & 5.23 & Gammarella fucicola & & 0.7 & 5.05 \\
\hline Gammarella fucicola & & 0.71 & 4.69 & Lysianassa costae & & 0.68 & 4.44 \\
\hline \multirow[t]{4}{*}{ Quadrimaera inaequipes } & & 0.72 & 4.22 & Chondrochelia savignyi & & 0.62 & 4.34 \\
\hline & & & & Quadrimaera inaequipes & & 0.72 & 4.2 \\
\hline & & & & Elasmopus pocillimanus & & 0.46 & 3.65 \\
\hline & & & & Cerithium sp. & & 0.57 & 3.59 \\
\hline
\end{tabular}


491

\section{Figure captions}

Figure 1. Study area with sampling sites (Site 1, 2 and 3). The dotted line marks the separation between the central-northern and the southern sub-basins (from La Loggia et al., 2004).

Figure 2. Dry mass (g) of $P$. oceanica leaf detritus remaining in the litterbags after $0,3,7,14,47,101,152$, 221 days in the three sites. Exponential decay fitting lines were reported as black dotted (Site 1), grey dotted (Site 2) and black full (Site 3) lines.

Figure 3. Mean ( \pm s.d.) $\mathrm{C} \%, \mathrm{~N} \%$ and $\mathrm{C}: \mathrm{N}$ of $P$. oceanica leaf detritus remaining in the litterbags after $0,3,7$, $14,47,101,152,221$ days in the three sites.

Figure 4. Total density (ind. $g^{-1} \mathrm{DM}$ of detritus, mean \pm s.d.) and mean density (ind. $\mathrm{g}^{-1} \mathrm{DM}$ ) of each invertebrate group (A, Anellida Polychaeta; B, Arthropoda Amphipoda; C, Arthropoda Isopoda; D, Arthropoda Tanaidacea; E, Mollusca Bivalvia; F, Mollusca Gastropoda) found in the litterbags during the experiment in the three sites.

Figure 5. Total biomass ( $\mathrm{mg} \mathrm{g}^{-1} \mathrm{DM}$ of detritus, mean \pm s.d.) and mean biomass ( $\mathrm{mg} \mathrm{g}^{-1} \mathrm{DM}$ ) of each invertebrate group (A, Anellida Polychaeta; B, Arthropoda Amphipoda; C, Arthropoda Isopoda; D, Arthropoda Tanaidacea; E, Mollusca Bivalvia; F, Mollusca Gastropoda) found in the litterbags during the experiment in the three sites. 


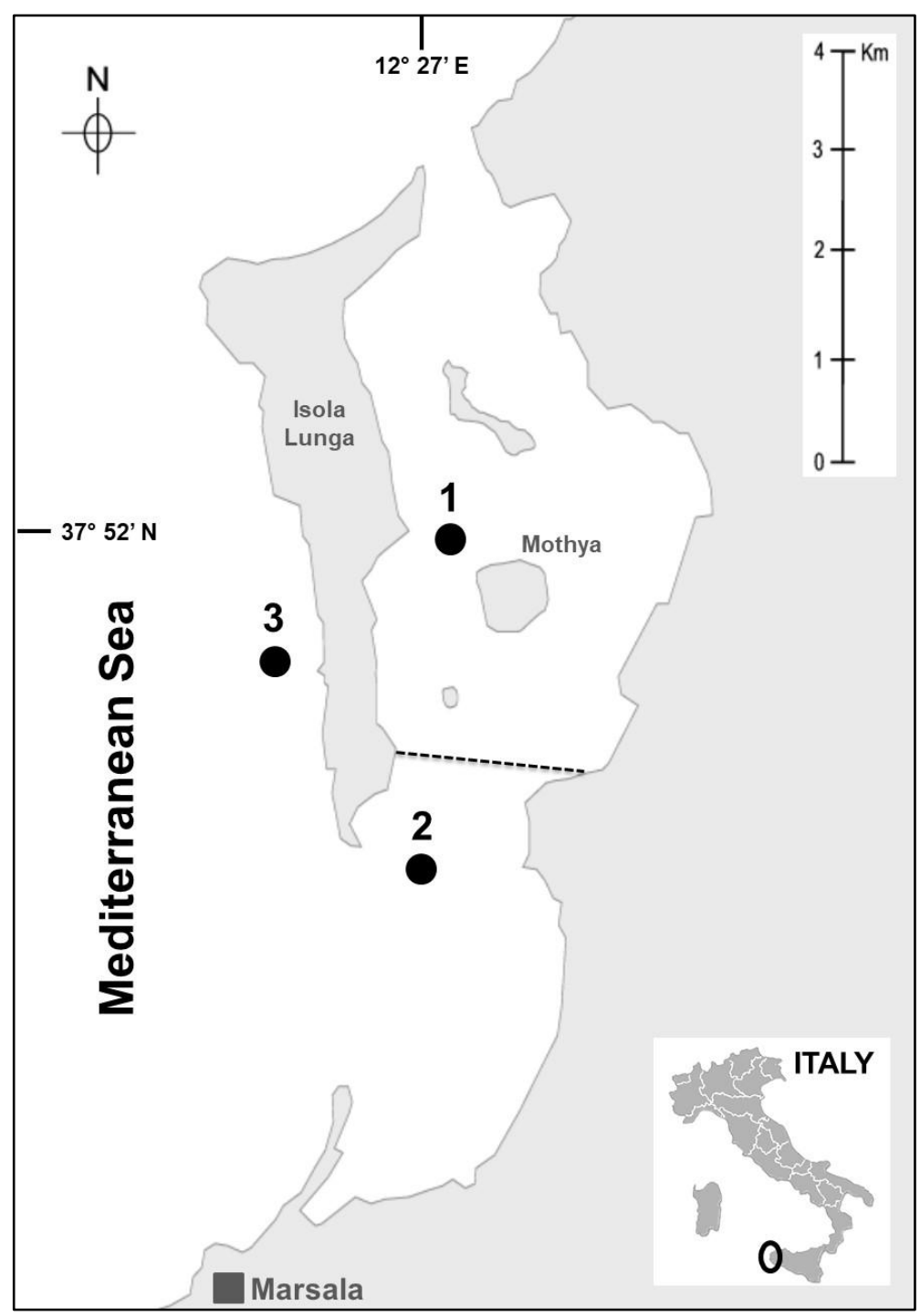

Fig. 1 


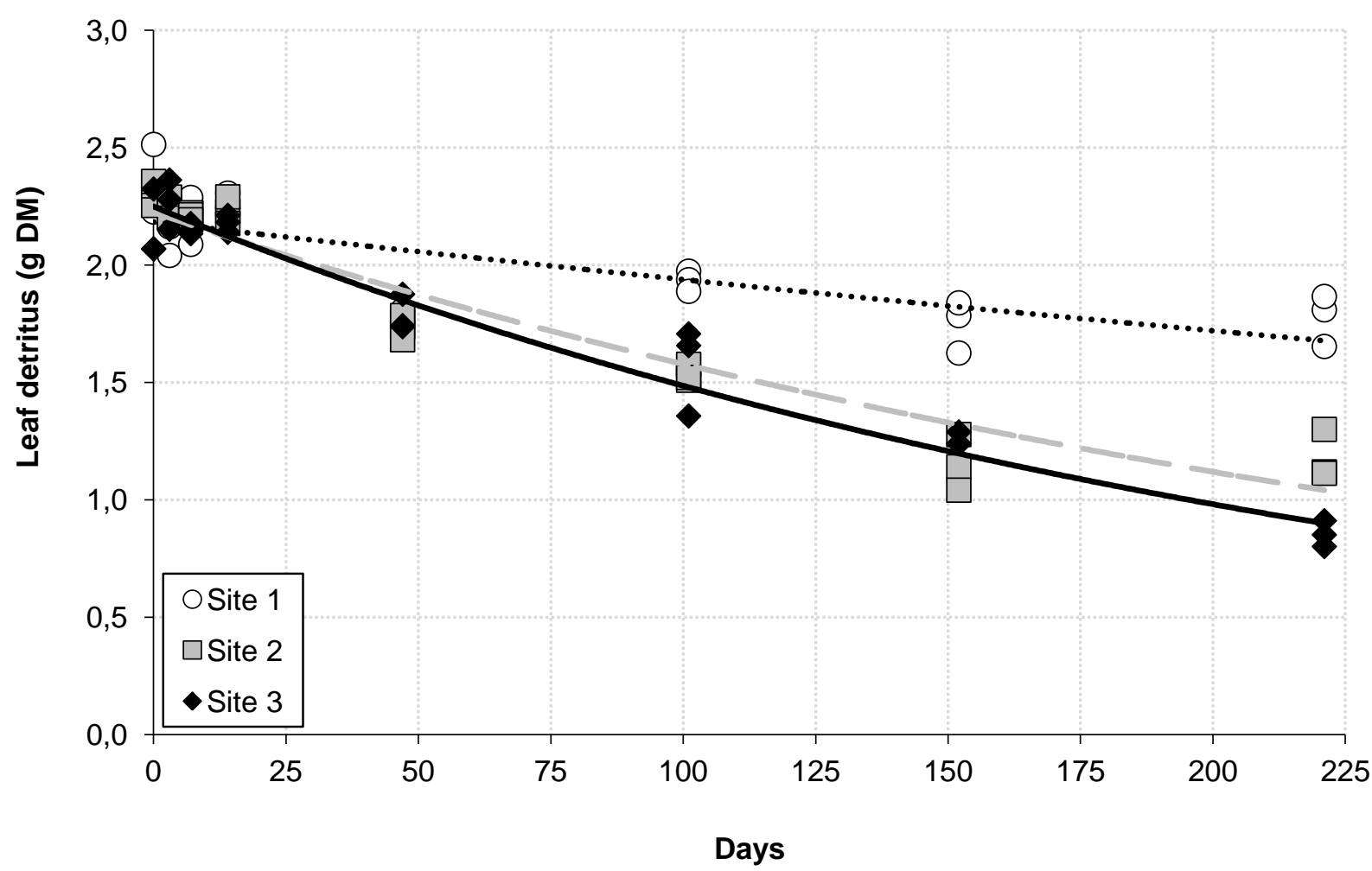



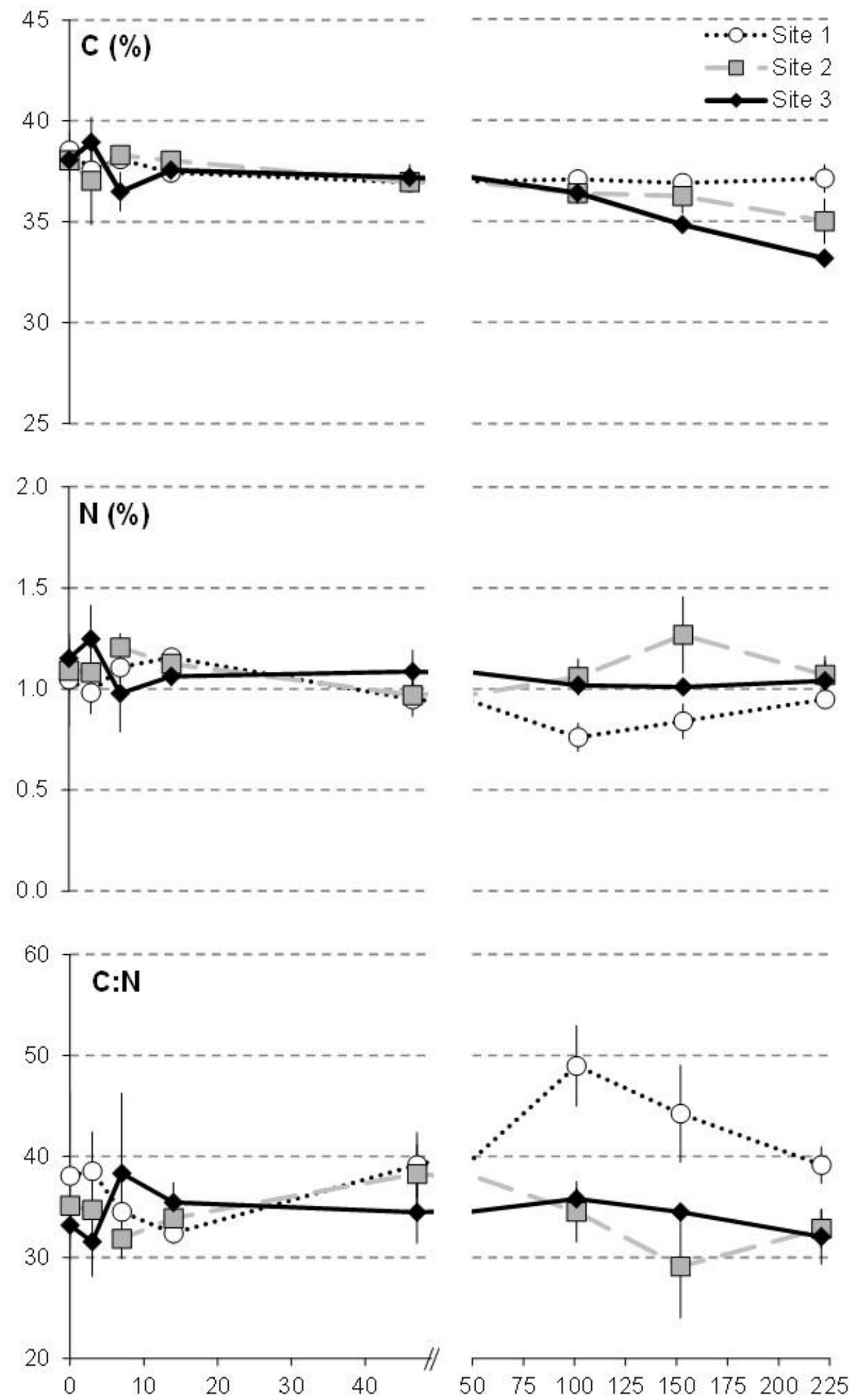

Fig. 3 

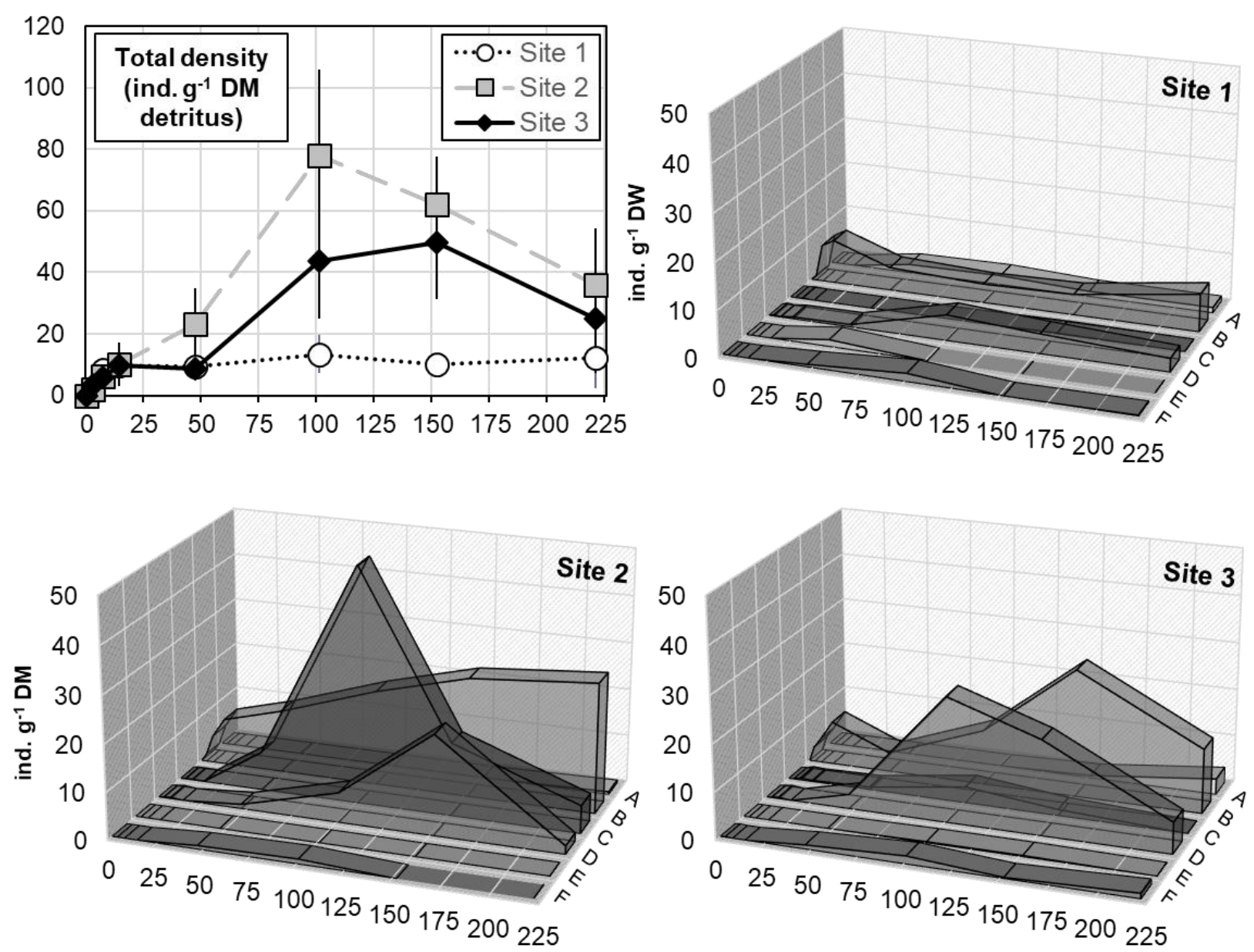

Days

Fig. 4 

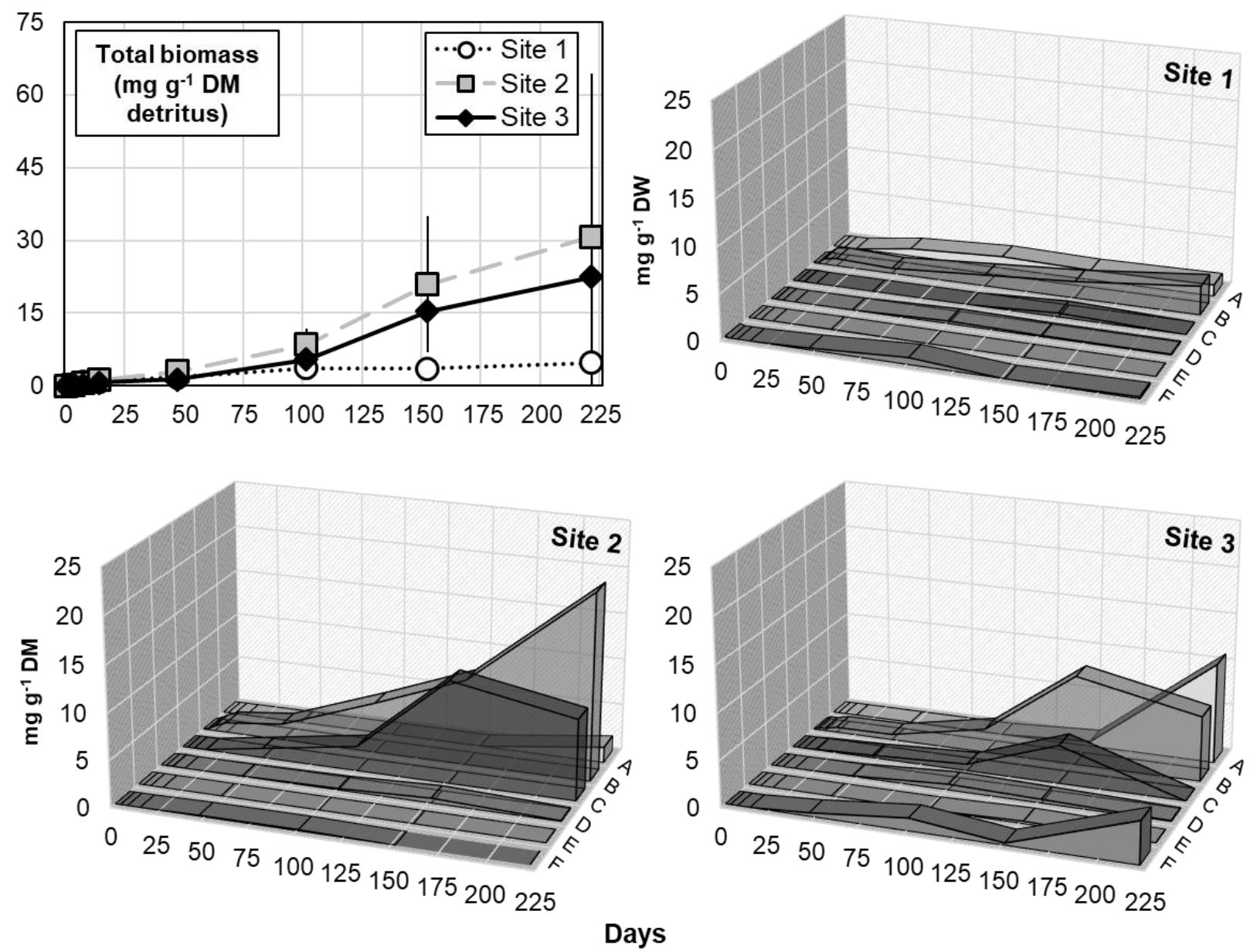

Days

Fig. 5 